\title{
Moderating Effect of Ethnicity on the Purchase Decisions of Females in the Beauty Care Product Market of Sri Lanka
}

\author{
Cooray N.S.D. ${ }^{1}$, Dias P.A.K ${ }^{1}$, Rajapaksha R.P.K.N ${ }^{1}$, Bernard K. ${ }^{1}$, Samarasinghe H.M.U.S.R ${ }^{1}$ \\ ${ }^{1}$ Faculty of Business, Sri Lanka Institute of Information Technology, Sri Lanka \\ Correspondence: Samarasinghe H.M.U.S.R, Faculty of Business, Sri Lanka Institute of Information Technology, \\ Sri Lanka.
}

Received: October 2, 2018

Accepted: October 25, 2018

Online Published: November 2, 2018

doi:10.5539/ibr.v11n12p12

URL: https://doi.org/10.5539/ibr.v11n12p12

\begin{abstract}
The main focal point in the eye of any marketer should be to satisfy the customer to the best possible level, in order to sustain in the ever-growing, dynamic and highly competitive marketplace. This leads them to the point where understanding the process of consumer buying behavior is of utmost importance. As the entire process of consumer buying behavior ultimately leads to their purchasing decision, deep understanding of the factors that affect this purchase decision should be the centralized core based on which all other marketing efforts should be built upon by the marketers. Based on this vitality, although these factors have already been found by past researchers in international contexts, these cannot be considered as directly applicable to the Sri Lankan context as Sri Lanka is a multiethnic country in which consumers are heavily driven by traditions and values of the ethnic group they belong to. Therefore, this study has been conducted in order to analyze the moderating effect of "Ethnicity" on the relationship between these factors and the purchasing decision.

The sample has been selected through Random Sampling and the Quantitative Research Approach has been applied. Chi-Square analysis method has been used to analyze the relationships between the independent variables (price, brand name and composition) and dependent variable (purchase decision). Two-way Anova analysis method has been used to analyze the moderating effect of the moderating variable (ethnicity) on the relationships between independent variables and the dependent variable. Based on interpretation guidelines of Chi-square test, all three independent variables, namely price, brand name and composition, affect the purchase decision of females in the beauty care product market of Sri Lanka. Thereafter, based on the interpretation guidelines of Two-way Anova, research findings of the second analysis conclude that ethnicity of the Sri Lankan females of the beauty care product market (Sinhalese, Tamils and Muslims) affect the relationships between "brand name and purchase decision" and "composition and purchase decision", but does not affect the relationship between "price and purchase decision".
\end{abstract}

Keywords: consumer buying behavior, consumer purchase decision, price, brand name, composition, beauty care market, skin whitening market, females of Sri Lanka, ethnicity

\section{Introduction}

"Marketing is the science and art of exploring, creating, and delivering value to satisfy the needs of a target market at a profit" (Kotler, 2015). "One of the key success factors in effective marketing is consumer centricity" McDonald (2016.) In order to focus on consumer centricity, firms need to first understand the consumer and prioritize their needs and wants in order to deliver value to them ultimately. This leads to the fact that marketers should clearly and deeply understand the consumer buying behavior to carry out effective strategy formulation. According to Perner (2008), in the process of consumer buying behavior, the main focus point is on consumer purchase decision, because that is where all businesses begin and survive. Therefore, it can be argued that core of all marketing efforts should be based influencing and triggering the final purchase decision of consumers.

\section{Background of Study}

According to many researchers, it has been argued that consumer purchase decision in the skin care product market can be affected by many factors. According to D.Court, D.Elzinga, S.Mulder, and O.J.Vetvik(2013), “...different consumers are affected by different factors in making their purchase decision when purchasing skin care products". "In North America, even if the consumers select the same skin care brand, the factor which has influenced them to 
choose the brand is different", J. Jacoby, G. V. Johar and M. Morrin(2001). According to A.Kirmani (2013), "when purchasing skin cream, the decision of which brand to purchase heavily varies from person to person even if the buying motive is the same. This is because their decision is affected by many external factors such as the fragrance, color and manufacturing company, of the particular skin cream product". Moreover, according to J.Escalas (2013), it has been stated that in a study of 500 female university students in Jamaica, it has been identified that each consumer is motivated by a particularly different factor when making their final purchase decision in the skin care product market. "The ultimate objective of purchasing skin care products of all females is the same, which is to enhance their beauty. But, their product choice is not the same due to being affected by other internal and external factors", D.J. Macinnis and V.S.Folkes (2015). Furthermore, "although consumers choose their skin care products out of habit as they are used to particular brands, the first choice always depends on a particular fact which can vary from an advertisement to the color of the product package", D. Lentinl (2015).

When all of these details are taken into consideration, it is evident that purchasing decision in the skin care product market is affected by a myriad of internal and external factors. Past research have been done to examine these factors as explained below

According to C.Moungkhem and J.Surakiatpinyo (2010), main factors that affect consumer purchase decision in the cosmetic market are price, brand name and influence of spouse. Factors that affect purchase decision in the herbal care product market are price, brand name and composition, says Jacinta AtienoOkumu (2015). According to H.Y.Kim and J.E.Chung (2011), factors that affect consumer buying behavior in the skin care market are price, influence of closest friends and composition. Main factors that affect consumer purchase decision in the shampoo category are price, composition and celebrities used in advertisements, says G.Wijesundera, R.Abeysekera (2008). According to I.Kokoi (2011), the factors that affect purchase decision in the health care category are price brand name and advertisements. Furthermore, according to M.Huda and P.Sultan (2013), factors that affect purchase decision in the herbal market are advertisements, composition and brand name. Main factors that affect consumer motives in the soap market are package design, price and fragrance of package, says N.Souiden and M.Diagne (2015). Moreover, according to Joseph Scrannel (2013), factors that affect purchase decision in the beauty care market are price, color of package and composition. Finally, the main factors that affect the purchase decision in the beauty market are price, brand name and package design.

Researchers have carried out an analysis to examine the 3 factors which have the highest frequency according to past research; "Price, Brand name and Composition"

\subsection{Current Situation of Study and Knowledge Gap}

Price, brand name and composition have been generalized and accepted globally as the factors that affect purchase decision in the skin care product market based on past research findings. But, Sri Lanka is a multiethnic country, in which consumers are heavily driven by traditions and values of the ethnic group they belong to. "Ethnicity is a very sensitive subject area which directly impacts standards, opinions, values, attitudes and the thought processes of people and it can have humungous effects on consumer purchase decision. Purchase decisions even in a very niche market could be different from person to person based on their ethnicity". Moreover, "belonging to a certain ethnic group will affect the purchase decision of consumers to a certain extent in the herbal care product market. This is because there are different types of norms and values for each ethnic group. Therefore, it is agreeable to state that ethnicity have an effect on consumer purchase decision as researched and proved in international context. Thereby, these generalized factors might or might not be applicable and valid in the Sri Lankan context due to varying traditions, practices and habits followed by each ethnic group.

\subsection{Objectives of the Study}

1. To examine the moderating effect of ethnicity on the relationship between price and purchase decision of Sri Lankan females in the beauty care product market.

2. To examine the moderating effect of ethnicity on the relationship between brand name and purchase decision of Sri Lankan females in the beauty care product market.

3. To examine the moderating effect of ethnicity on the relationship between composition and purchase decision of Sri Lankan females in the beauty care product market.

\subsection{Research Questions}

1. Is there a significant moderating effect of ethnicity on the relationship between price and purchase decision of Sri Lankan females in the beauty care product market? 
2. Is there a significant moderating effect of ethnicity on the relationship between brand name and purchase decision of Sri Lankan females in the beauty care product market?

3. Is there a significant moderating effect of ethnicity on the relationship between composition and purchase decision of Sri Lankan females in the beauty care product market?

\section{Literature Review}

\subsection{Theoretical Reviews}

\begin{tabular}{|c|c|c|}
\hline Theoretical Review & Summary of theoretical review & Implication to research \\
\hline Ethnicity Theory & Different dimensions of ethnicity & $\begin{array}{l}\text { Important for the formulation of the research } \\
\text { questionnaire }\end{array}$ \\
\hline Ethnicity Theory & $\begin{array}{l}\text { Moderating effect of ethnicity on psychological } \\
\text { through processes of people }\end{array}$ & $\begin{array}{l}\text { Important for the formulation of research } \\
\text { problem statement, background of study and } \\
\text { knowledge gap }\end{array}$ \\
\hline $\begin{array}{l}\text { Consumer } \\
\text { Model }\end{array}$ & $\begin{array}{l}\text { Consumer behavior is a psychological thought } \\
\text { process }\end{array}$ & $\begin{array}{l}\text { Important for the formulation of research } \\
\text { problem statement, background of study and } \\
\text { knowledge gap }\end{array}$ \\
\hline Theoretical Review & Summary of theoretical review & Implication to research \\
\hline $\begin{array}{l}\text { Consumer } \quad \text { Decision } \\
\text { Model }\end{array}$ & $\begin{array}{l}\text { External and internal factors affect the } \\
\text { consumer purchase decision }\end{array}$ & $\begin{array}{l}\text { Important for the formulation of research } \\
\text { problem statement, background of study and } \\
\text { knowledge gap }\end{array}$ \\
\hline $\begin{array}{l}\text { Hofstede's } \\
\text { Diagram }\end{array}$ & Different dimensions of ethnicity & $\begin{array}{l}\text { Important for the formulation of the research } \\
\text { questionnaire }\end{array}$ \\
\hline $\begin{array}{l}\text { Hofstede's } \\
\text { Diagram }\end{array}$ & $\begin{array}{l}\text { How the different dimensions of ethnicity affect } \\
\text { the behavioral processes of people }\end{array}$ & $\begin{array}{l}\text { Important for the formulation of research } \\
\text { problem statement, background of study and } \\
\text { knowledge gap }\end{array}$ \\
\hline Functionalism & $\begin{array}{l}\text { Behavioral patterns of people fluctuate across } \\
\text { different ethnic boundaries }\end{array}$ & $\begin{array}{l}\text { Important for the formulation of research } \\
\text { problem statement, background of study and } \\
\text { knowledge gap }\end{array}$ \\
\hline $\begin{array}{l}\text { Consumer } \\
\text { Model }\end{array}$ & $\begin{array}{l}\text { External and internal factors affect the } \\
\text { consumer purchase decision }\end{array}$ & $\begin{array}{l}\text { Important for the formulation of research } \\
\text { problem statement, background of study and } \\
\text { knowledge gap }\end{array}$ \\
\hline $\begin{array}{l}\text { Hofstede's } \\
\text { Diagram } \\
\end{array}$ & Different dimensions of ethnicity & $\begin{array}{l}\text { Important for the formulation of the research } \\
\text { questionnaire }\end{array}$ \\
\hline \multicolumn{3}{|l|}{3.2 Empirical Reviews } \\
\hline Author & Empirical review & Part of the research to which it is applied \\
\hline Steven MacDonald (2016) & $\begin{array}{l}\text { Consumer centricity is key when marketing is } \\
\text { being considered }\end{array}$ & $\begin{array}{l}\text { Problem statement formulation - Background } \\
\text { of study }\end{array}$ \\
\hline Lars Perner (2008) & $\begin{array}{l}\text { Purchase decision is one of the most vital } \\
\text { points in the consumer behavior process }\end{array}$ & $\begin{array}{l}\text { Problem statement formulation - Background } \\
\text { of study }\end{array}$ \\
\hline $\begin{array}{l}\text { LMRB Household Panel } \\
\text { data (2014-2015) }\end{array}$ & $\begin{array}{l}\text { Amongst the sub-segments within the FMCG } \\
\text { sector of Sri Lanka, beauty care sub-category } \\
\text { reflects the highest monthly growth rate } \\
\text { compared to other sub-categories such as } \\
\text { home care, foods, etc. }\end{array}$ & $\begin{array}{l}\text { Problem statement formulation - Background } \\
\text { of study }\end{array}$ \\
\hline $\begin{array}{l}\text { LMRB Household Panel } \\
\text { data (2014-2015) }\end{array}$ & $\begin{array}{l}\text { Within the beauty care market of Sri Lanka, } \\
\text { the highest contribution is from the skin } \\
\text { whitening cream sub-category compared to } \\
\text { other sub-categories such as cosmetics, } \\
\text { perfumes, etc. }\end{array}$ & $\begin{array}{l}\text { Problem statement formulation - Current } \\
\text { situation in the Sri Lankan context and } \\
\text { Knowledge gap }\end{array}$ \\
\hline $\begin{array}{l}\text { HeeYeon Kim and Jae-Eun } \\
\text { Chung (2011) }\end{array}$ & $\begin{array}{l}\text { Main factors that affect consumer buying } \\
\text { behavior in the skin care market are price, } \\
\text { influence of closest friends and composition }\end{array}$ & $\begin{array}{l}\text { Problem statement formulation - Current } \\
\text { situation in the Sri Lankan context and } \\
\text { Knowledge gap }\end{array}$ \\
\hline $\begin{array}{l}\text { Chanintorn Moungkhem } \\
\text { and Jiraporn Surakiatpinyo } \\
(2010)\end{array}$ & $\begin{array}{l}\text { Main factors that affect consumer purchase } \\
\text { decision in the cosmetic market are price, } \\
\text { brand name and influence of spouse }\end{array}$ & $\begin{array}{l}\text { Problem statement formulation - Current } \\
\text { situation in the Sri Lankan context and } \\
\text { Knowledge gap }\end{array}$ \\
\hline $\begin{array}{l}\text { Jacinta Atieno Okumu } \\
(2015)\end{array}$ & $\begin{array}{l}\text { Main factors that affect purchase decision in } \\
\text { the herbal care product market are price, } \\
\text { brand name and composition }\end{array}$ & $\begin{array}{l}\text { Problem statement formulation - Current } \\
\text { situation in the Sri Lankan context and } \\
\text { Knowledge gap }\end{array}$ \\
\hline $\begin{array}{l}\text { HeeYeon Kim and Jae-Eun } \\
\text { Chung (2011) }\end{array}$ & $\begin{array}{l}\text { Main factors that affect consumer buying } \\
\text { behavior in the skin care market are price, } \\
\text { influence of closest friends and composition }\end{array}$ & $\begin{array}{l}\text { Problem statement formulation - Current } \\
\text { situation in the Sri Lankan context and } \\
\text { Knowledge gap }\end{array}$ \\
\hline $\begin{array}{l}\text { Chanintorn Moungkhem } \\
\text { and Jiraporn Surakiatpinyo } \\
\text { (2010) }\end{array}$ & $\begin{array}{l}\text { Main factors that affect consumer purchase } \\
\text { decision in the cosmetic market are price, } \\
\text { brand name and influence of spouse }\end{array}$ & $\begin{array}{l}\text { Problem statement formulation }- \text { Current } \\
\text { situation in the Sri Lankan context and } \\
\text { Knowledge gap }\end{array}$ \\
\hline
\end{tabular}




\begin{tabular}{|c|c|c|}
\hline $\begin{array}{l}\text { Jacinta AtienoOkumu } \\
\text { (2015) }\end{array}$ & $\begin{array}{l}\text { Main factors that affect purchase decision in } \\
\text { the herbal care product market are price, } \\
\text { brand name and composition }\end{array}$ & $\begin{array}{l}\text { Problem statement formulation - Current } \\
\text { situation in the Sri Lankan context and } \\
\text { Knowledge gap }\end{array}$ \\
\hline AmnaKirmani (2013) & $\begin{array}{l}\text { When purchasing skin cream, the decision of } \\
\text { which product to purchase heavily varies from } \\
\text { person to person even if the buying motive is } \\
\text { the same. This is because their decision is } \\
\text { affected by many external factors such as the } \\
\text { fragrance, color, manufacturing company, etc. } \\
\text { of the particular skin cream product }\end{array}$ & $\begin{array}{l}\text { Problem statement formulation - Current } \\
\text { situation in the Sri Lankan context and } \\
\text { Knowledge gap }\end{array}$ \\
\hline Trading Economics (2014) & $\begin{array}{l}\text { "Females of Sri Lanka" accounts to } 51.75 \% \text { of } \\
\text { Sri Lankan population }\end{array}$ & $\begin{array}{l}\text { Population and Sample - Selection of the } \\
\text { population }\end{array}$ \\
\hline $\begin{array}{l}\text { World Bank Indicators } \\
\text { (2014) }\end{array}$ & $\begin{array}{l}\text { Out of a total of } 20 \text { million people in Sri Lanka } \\
(20,639,000 \text { accurately), the female } \\
\text { population accounts to over } 10 \text { million } \\
(10,680,682.5 \text { accurately) as of the year } 2014\end{array}$ & $\begin{array}{l}\text { Population and Sample - Selection of the } \\
\text { population }\end{array}$ \\
\hline
\end{tabular}

\section{Methodology}

\subsection{Conceptual Framework}

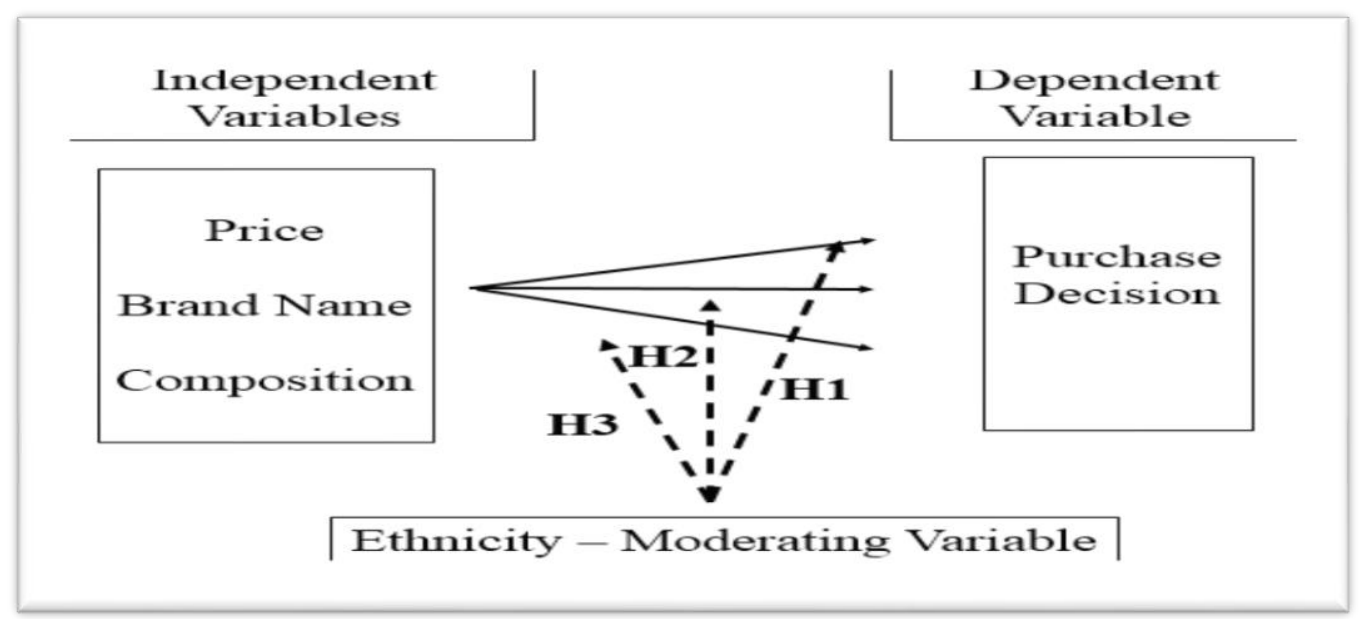

Source: Authors

\subsection{Hypotheses of Study}

- $\mathrm{H}_{1}$ - There is a significant moderating effect of ethnicity on the relationship between price and purchase decision of Sri Lankan females in the beauty care product market

- $\mathrm{H}_{2}$ - There is a significant moderating effect of ethnicity on the relationship between brand name and purchase decision of Sri Lankan females in the beauty care product market

- $\mathrm{H}_{3}$ - There is a significant moderating effect of ethnicity on the relationship between composition and purchase decision of Sri Lankan females in the beauty care product market

\subsection{Population}

As the research focuses on purchase decision of Sri Lanka females, the population is Sri Lankan females .

\subsection{Sample}

The sample selected consists of a total of 470 machine operators randomly selected based on employee databases of Brandix Intimates, MAS and Hela Clothing in Sri Lanka

\subsubsection{Sampling Method}

Random sampling method has been used in order to select the sample for the study. Frame of reference for sampling was females of garment factories of Sri Lanka.

\subsubsection{Measurement Instruments}

The sole measurement instrument used in this study is a manually distributed questionnaire developed based on the "Quantitative Approach". The questionnaire consists of 22 questions which covers the main attributes of each of the 2types of variables (independent and dependent). The 22 questions span in such a way to cover all the 
attributes of "Purchase decision, Price, Brand Name and Composition

\subsection{Research Methods}

\subsubsection{Pilot Study}

The "Pilot Study" of this study has been conducted among 45 randomly selected respondents. The data gathered through this study were recorded on an excel sheet based on the variables and attributes of the distributed questionnaire. The data were then exported to SPSS and the "Reliability Test" of the research questionnaire was done through "SPSS Version 22".

\subsubsection{Reliability Test}

As the Cronbach's alpha values of the test for all Likert scale based questions are above 0.75 , which is the Cronbach's alpha error rate, it can be concluded that all of the 22 Likert scale based questions included in the questionnaire of this study are reliable

\subsubsection{Data Collection}

Main data collection method used which has been used is "Primary Data Collection" as the researches have personally visited the selected sample and carried out data collection.

\subsubsection{Data Analysis}

SPSS Version 22 has been used to carry out data analysis. Chi-square test has been used to analyze the relationship between the dependent variables and the independent variable. Two-way anova has been used to test the moderating effect

\section{Results and Interpretation}

\begin{tabular}{ll}
\hline Chi-square Test Results & \\
\hline Relationship & "p" value according to analysis \\
Relationship between purchase decision and price & 0.001 \\
Relationship between purchase decision and brand name & 0.002 \\
Relationship between purchase decision and composition & 0.003 \\
\hline
\end{tabular}

\begin{tabular}{|c|c|}
\hline \multicolumn{2}{|l|}{ Two-way Anova Test Results } \\
\hline Relationship & "Sig" value according to analysis \\
\hline $\begin{array}{l}\text { Moderating effect of ethnicity on the relationship between } \\
\text { purchase decision and price }\end{array}$ & 0.427 \\
\hline $\begin{array}{l}\text { Moderating effect of ethnicity on the relationship between } \\
\text { purchase decision and brand name }\end{array}$ & 0.000 \\
\hline $\begin{array}{l}\text { Moderating effect of ethnicity on the relationship between } \\
\text { purchase decision and composition }\end{array}$ & 0.000 \\
\hline \multicolumn{2}{|c|}{$\begin{array}{l}\text { As the chi-square test value of all } 3 \text { relationships between dependent and independent variable are below } 0.05 \\
\text { (the error factor), the null hypotheses have been rejected and the research hypotheses have been accepted. As the } \\
\text { two-way anova test value is lower than } 0.05 \text { (error factor) for the relationships between brand name and } \\
\text { composition, the null hypotheses have been rejected and research hypotheses have been accepted, but for price, } \\
\text { since the test value is above } 0.05 \text {, the null hypothesis has been accepted. }\end{array}$} \\
\hline
\end{tabular}

\section{Recommendations}

In the field of marketing customer is considered as the key without whom a market will not exist in the first place. Therefore, the main focal point in the eye of any marketer should be to satisfy the customer to the best possible level, in order to sustain in the ever growing, dynamic and highly competitive marketplace. This leads them to the point where understanding the process of consumer buying behavior is of utmost importance. As the entire process of consumer buying behavior ultimately leads to their purchasing decision, deep understanding of the factors that affect this purchase decision should be built upon by the marketers. Therefore the findings of this research area significant support for the marketers in the beauty care product market of sri lanka for formulating their strategies effectively in a way which convinces and triggers the consumer purchasing decisions. This includes all promotional efforts which would include all the elements of the "Marketing Mix". For example, based on findings of this research it has been concluded that all three factors "Price, Brand Name and Composition "affect the purchasing decisions of females in the beauty care product market of Sri Lanka. Therefore, when designing marketing campaigns or simply and advertisements for a new product launch in the skin whitening product market, the advertisement should clearly and distinguishably mention the price , brand name and the composition of the product. 


\section{Conclusion}

The research aims to test 3 different research hypotheses; which imply that there is a relationship between each of the independent variable and the dependent variable When a sample of 470 females in the beauty care product market of Sri Lanka, which was randomly selected, was analyzed, it has been found that the purchasing decision of these females when buying skin whitening cream was affected by 3 main factors; Price, Brand name and Composition. Moreover, when a sample of 470 females in the beauty care product market of Sri Lanka, which was randomly selected, was analyzed, it has been found that their ethnicity affects the relationship between price of product and purchasing decision of these females when buying skin whitening cream and their ethnicity does not affect the relationship between brand name and purchase decision and composition and purchasing decision of these females when buying skin whitening cream.

\section{References}

Boduszek, D. (2011). Chi Square test of independence and McNemer Test .

Chandler, S. (2012). What is SPSS. Canada.

Choudhury, A., \& Mukherjee, K. (2014). Celebrity Endorsmenet and its Impacts on Studnets Buying Behavior towards Persoanl Care Products. Journal of Marketing , 50-62.

Das, S., \& Padhy , P. K. (2012). Brand perception by external factors. International Journal of Advanced Research, 25-38.

Dissanayake \& Weerasiri. (2007). Involvement of Personnel Endorsements for building Brand. Kelaniya Journal of Management, 20-36.

Doss, S. (2012). The transference of brand attitude : the effect on the celebrity endorser. Journal of Management and Marketing Reserach.

Dudovskiy, J. (2011). An ultimate guide to write a dissertation .

Gupta, S. (2006). Celebrity Endorsement . India: Slideshare .

H. C., K. (1979). The Role of Action inAttitude change . University of Nebraska Press .

Hilary, J. (2008). The research Process. Retrieved from https://businessmanagement.wordpress.com .

Hovland , C., Janis , I., \& Kelly, H. (1953). Communication and Persuasion .

Jain , V. (2011). Clebrity Endorsement and its impact on sales. Global Journals, 45-59.

Kasana, J., \& Chaudhary, N. (2014). Impact of External factors on Consumer buying behavior. International Reserach Journal of Commerce, Arts and Science, 25-33.

Kelly. (1973). Attribution Theory.

Kumar, A. (2010). Factors and its impact on consumer buying behavior . United Kingdom .

Louis. (2008). DJS Reaserch. Retrieved from Quantititave Reserach: http://www.marketreseachworld.net/content/view/393/42

McCracken, G. (1989). Who is the Celebrity Endorser? Cultural Foundations of the Endorsement Process. Journal of Consumer Research, 16(3), 310-321. https://doi.org/10.1086/209217

T.N.Compnany. (2014). Review and Oppurtunities. Sri Lanka .

Trading Economics. 2014

World Bank Indicators., 2014

\section{Copyrights}

Copyright for this article is retained by the author(s), with first publication rights granted to the journal.

This is an open-access article distributed under the terms and conditions of the Creative Commons Attribution license (http://creativecommons.org/licenses/by/4.0/). 